$\therefore$

$\therefore$ FEB

51962

\author{
GENERAL ATOMIC DIVISION \\ GENERAL DYNAMICS CORPORATION \\ John Jay Hopkins Laboratory for Pure and Applied Sclences \\ P. 0. Box 608, San Diego 12, California
}

MASTER

\author{
GAMD-2476 \\ Category A \\ Copy No.
}

Processing of Graphlte Specimens for HIgh

Temperature Irradiation by Hanford

Work done by:

Report written by:

B. F. Disselhorst

G. B. Engle

G. R. Tully

P. R. Macy

J. Lindgren

G. B. Engle

This document, which was prepared primarliy for Internal use at General Atomlc, may contain preIiminary or incomplete data. It is informal and is subject to revision or correction; it does not, therefore, represent a final report. 


\section{DISCLAIMER}

This report was prepared as an account of work sponsored by an agency of the United States Government. Neither the United States Government nor any agency Thereof, nor any of their employees, makes any warranty, express or implied, or assumes any legal liability or responsibility for the accuracy, completeness, or usefulness of any information, apparatus, product, or process disclosed, or represents that its use would not infringe privately owned rights. Reference herein to any specific commercial product, process, or service by trade name, trademark, manufacturer, or otherwise does not necessarily constitute or imply its endorsement, recommendation, or favoring by the United States Government or any agency thereof. The views and opinions of authors expressed herein do not necessarily state or reflect those of the United States Government or any agency thereof. 


\section{DISCLAIMER}

Portions of this document may be illegible in electronic image products. Images are produced from the best available original document. 
INTRODUCTION

A graphite irradiation experiment is being conducted jointly by General Atomlc and Hanford. The objective is to determine the effect of varlous heat treatments and Impregnation on the electrical resistivity, structural parameters, and irradiation effects. The pre-irradiation processing was performed at General Atomic, and the x-ray analysis and irradiation experiments will be done by Hanford. This report includes the work done at G. A. prior to shipping the samples to Hanford.

Material

The base graphite for the experiment was NCC's NPR-core, and GLCC's HLM-85. The HMM-85, impregnated with furfuryl alcohol, is of current interest to the HTGR as a sleeve material, and the NPR-core graphite is of interest to Hanford and G. A. as a stable in-pile structural, reflector, and moderator materlal. Both base graphites are manufactured from a petroleum coke filler bonded with coal tar pitch. The NPR-core graphite is manufactured from "needle coke" which has been recommended in the past as a stable graphite under high temperature irradiation. The HLM-85 has a fine pore structure and can be Impregnated to obtain low gas permeability while the NPR-core graphite has an open structure. A diagram of the sample shape and dimensions is shown in Figure 1.

\title{
Irradiation Conditions
}

The irradiation conditions will be specified by Hanford. However, 1t Is understood the samples will be irradiated in uncontrolled capsules in the MTR core above $1000^{\circ} \mathrm{C}$ to relatively high nvt.

Experimental Work

The processing consisted of an inftial heat treatment of the as manufactured base stock at $2900^{\circ} \mathrm{C}$ for about one-half hour, and subsequent Impregnation, carbonization of the impregnant and final heat treatment to 2650 or $2900^{\circ} \mathrm{C}$. The effect of heat treatments and impregnant coke on the electrical resistivity of the graphite samples is given in Table 1 .

\author{
620
}




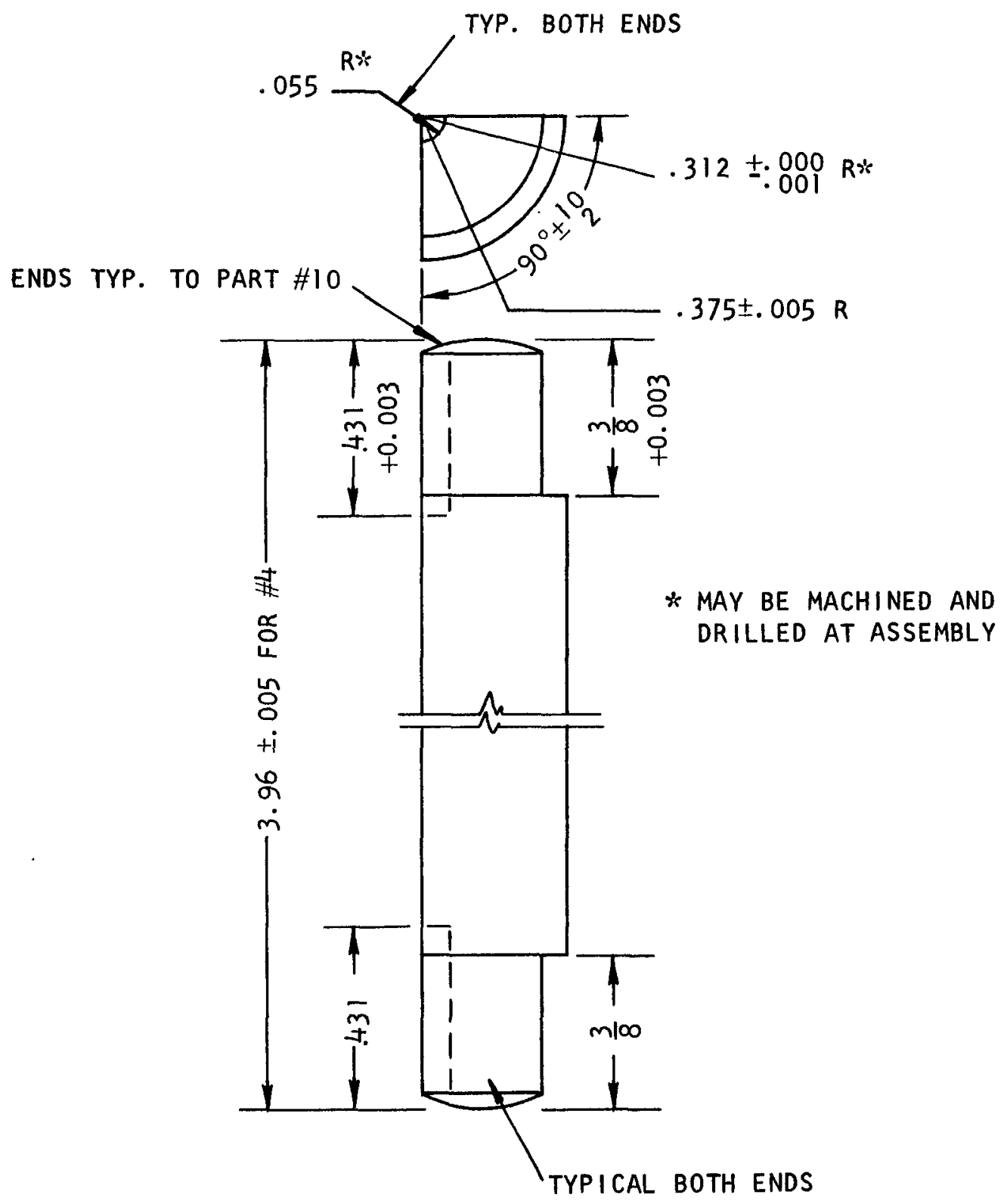

IPIGURE I GRAPHITE IRRADIATION SAMPLES

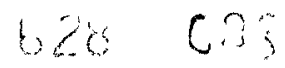


TABLE 1.

SAMPLE

Number Source Type $\begin{aligned} & \text { Orientation with Respect } \\ & \text { to Extrusion Force }\end{aligned}$

\begin{tabular}{|c|c|c|c|}
\hline$E W-164-X 1$ & $\mathrm{EW}-\mathrm{NCC}$ & NPR & Perpendicular \\
\hline $\mathrm{HN}-164-\mathrm{X} 2$ & $\mathrm{HW}-\mathrm{NCC}$ & $\mathrm{NPR}$ & Perpendicular \\
\hline$H W-164-X 3$ & $\mathrm{EW}-\mathrm{NCC}$ & NPR & Perpendicular \\
\hline$B N-164-X 4$ & $\mathrm{HW}-\mathrm{NCC}$ & NPR & Perpendicular \\
\hline $\mathrm{HW}-164-\mathrm{X} 10$ & $\mathrm{HW}-\mathrm{NCC}$ & $\mathrm{NPR}$ & Perpendicular \\
\hline$H: N-164-X I 1$ & $\mathrm{EW}-\mathrm{NCC}$ & NPR & Perpendicular \\
\hline$H N-164-X I 2$ & $\mathrm{HW}-\mathrm{NCC}$ & NPR & Perpendicular \\
\hline KN $164-X 13$ & $\mathrm{H} W \mathrm{~N}-\mathrm{NCC}$ & $\mathrm{NPR}$ & Perpendicular \\
\hline$B N-164-201 X$ & $\mathrm{HW}-\mathrm{NCC}$ & NPR & Parallel \\
\hline $5 N-164-202 X$ & IN-NCC & NPR & Parallel \\
\hline$H W-164-203 X$ & $\mathrm{HW}-\mathrm{NCC}$ & NPR & Parallel \\
\hline पn-104-204X & $\mathrm{HW}-\mathrm{NCC}$ & NPR & Parallel \\
\hline$\pi /-164-205 x$ & $\mathrm{HW}-\mathrm{NCC}$ & NPR & Parallel \\
\hline$\pi N-164-206 \mathrm{X}$ & $\mathrm{HW}-\mathrm{NCC}$ & NPR & Parallel \\
\hline तN-164-207X & $\mathrm{HW}-\mathrm{NCC}$ & NPR & Parallel \\
\hline $7 N-164-208 x$ & $\mathrm{HW}-\mathrm{NCC}$ & $\mathrm{NPR}$ & Parallel \\
\hline GA-1494-7-I & GA-GLCC & $\mathrm{HLM}-85$ & Parallel \\
\hline GA-1494-7-2 & GA-GLCC & HLM- 85 & Parallel \\
\hline GA-1494-7-3 & GA-GLCC & HIM -85 & Parallel \\
\hline $\mathrm{GA}-1494-7-4$ & GA-GLCC & HIM-85 & Parallel \\
\hline GA-1494-7-5 & GA-GLCC & $\mathrm{ELM}-85$ & Parallel \\
\hline GA-1494-7-6 & GA-GLCC & HIM-85 & Parallel \\
\hline$G A-1494-7-7$ & GA-GLCC & HLM-85 & Parallel \\
\hline GA-1494-7-8 & GA-GLCC & HLM-85 & Parallel \\
\hline
\end{tabular}

EFFECT OF HEAT TREATMENTS AND IMPREGNANT

COKE ON ELECTRICAL RESISTIVITY

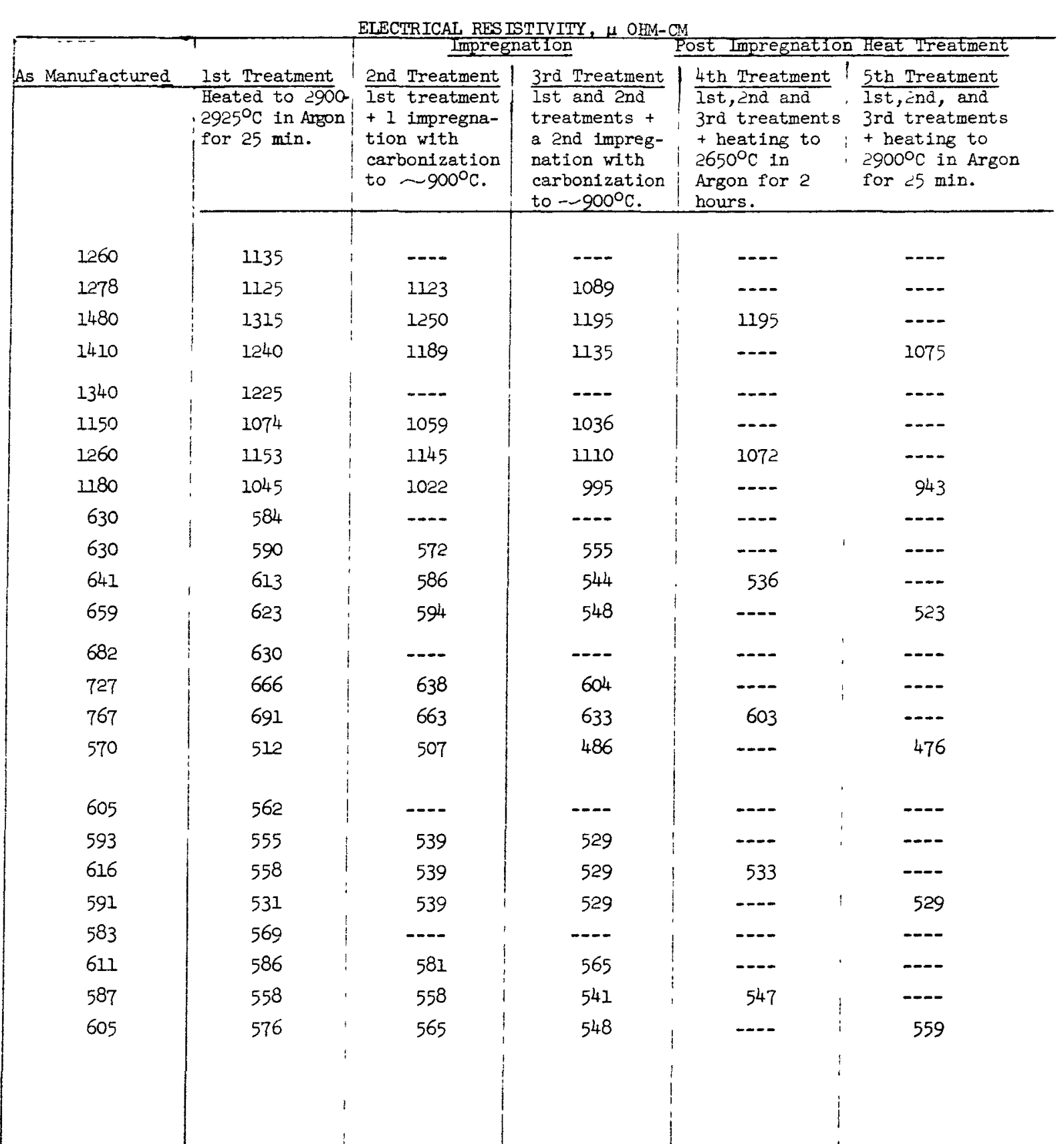


Discussion of Results

An initial reduction in electrical resistivity was observed after heat Ing the as manufactured material to $2900-2925^{\circ} \mathrm{C}$. Subsequent heat treatments and impregnations reduced the resistivity only slightly. There was conslderably more scatter in the electrical resistivity data of the NPR-core material as manufactured than for the HIM-85, and the scatter remained through subsequent treatments (See Figures 2 and 3). The HLM-85 is apparently more homogeneous than the NPR-core material. High final heat treatment $\left(2900^{\circ} \mathrm{C}\right)$ did not $1 \mathrm{~m}-$ prove on this characteristic.

The effect of carbon pickup on electrical resistivity of the $1 \mathrm{~m}$ pregnated samples is shown in Figures 4 and 5. The NPR-core graphite's open pore structure 1s apparent from the large carbon pick up (F1gure 4) compared to that of HLM-85 (Figure 5). When the NPR-core samples were cut parallel to extrusion, there was a definite correlation of carbon pick up with resistivity; (see dotted Iines in Figure 4) the material of higher resistivity soaked up the most carbon. This correlation was not as pronounced for samples cut perpendicular to extrusion. The correlation was not observed in HLM-85 samples, however, the resistivity values were quite close together in all HLM-85

samples. Thus, the resistivity measurements may not have been sensitive enough to show the effect.

$X$-ray diffraction samples were scraped frorn each sample after each processing step. The $\mathrm{x}$-ray samples, along with the irradiation samples, were shipped to Hanford.

Eर० (19) 


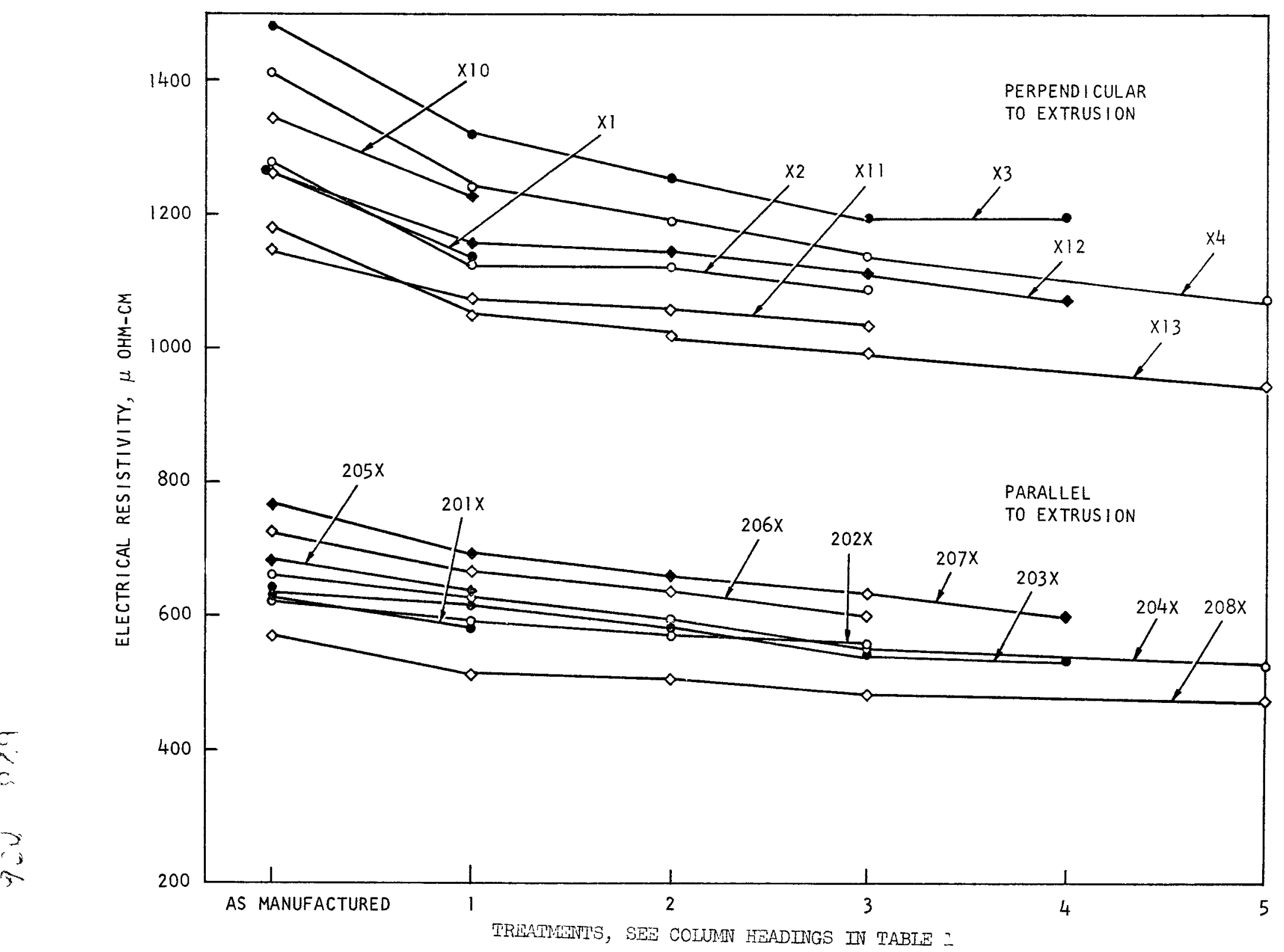

FIGURE 2 ELECTRICAL RESISTIVITY VERSUS TREATHETIS OF NPR-CORE GRAPUITE 


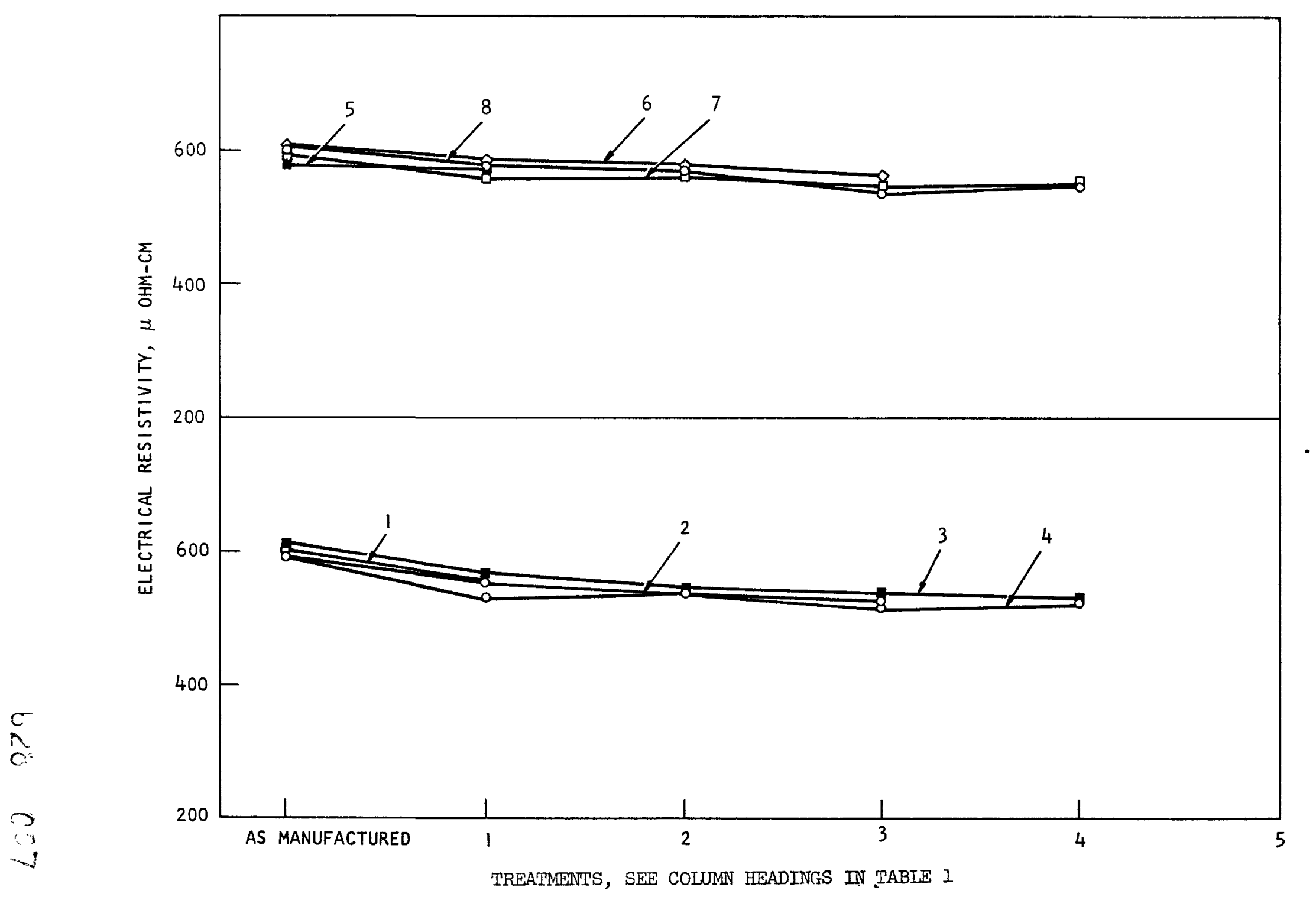

FIGURE 3 ELECTRICAL RESISTIVITY VERSUS TREATMENIS OF HLM-85 GRAPHTIE PARALIEL TO EXTRUSION 


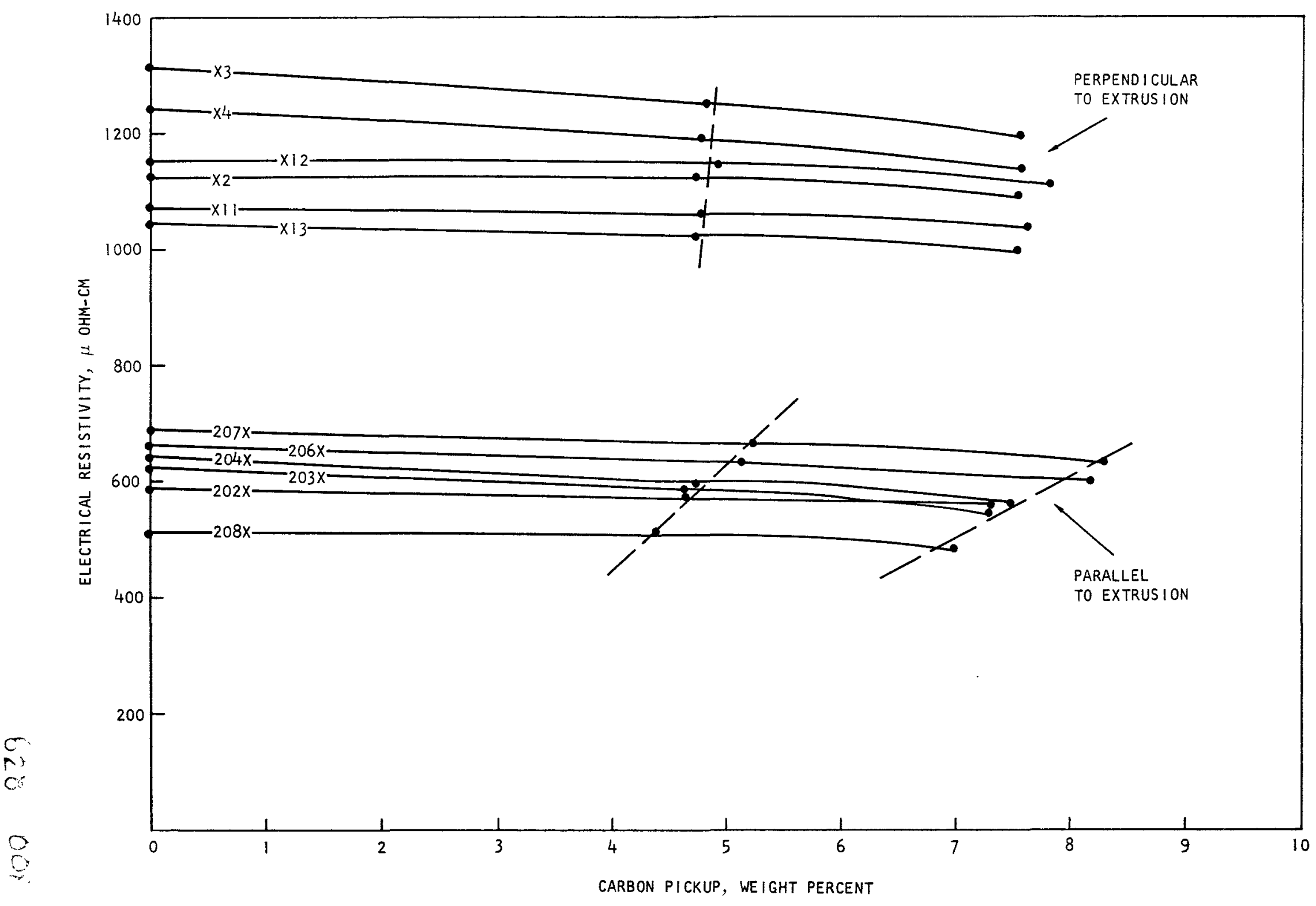

FIGURE 4 EFFECT OF CARBON PICKUP DURDNG IMPREGNATION CN ELECTRICAL RESISTIVTIY OF NPR-CORE GRAPHITE 


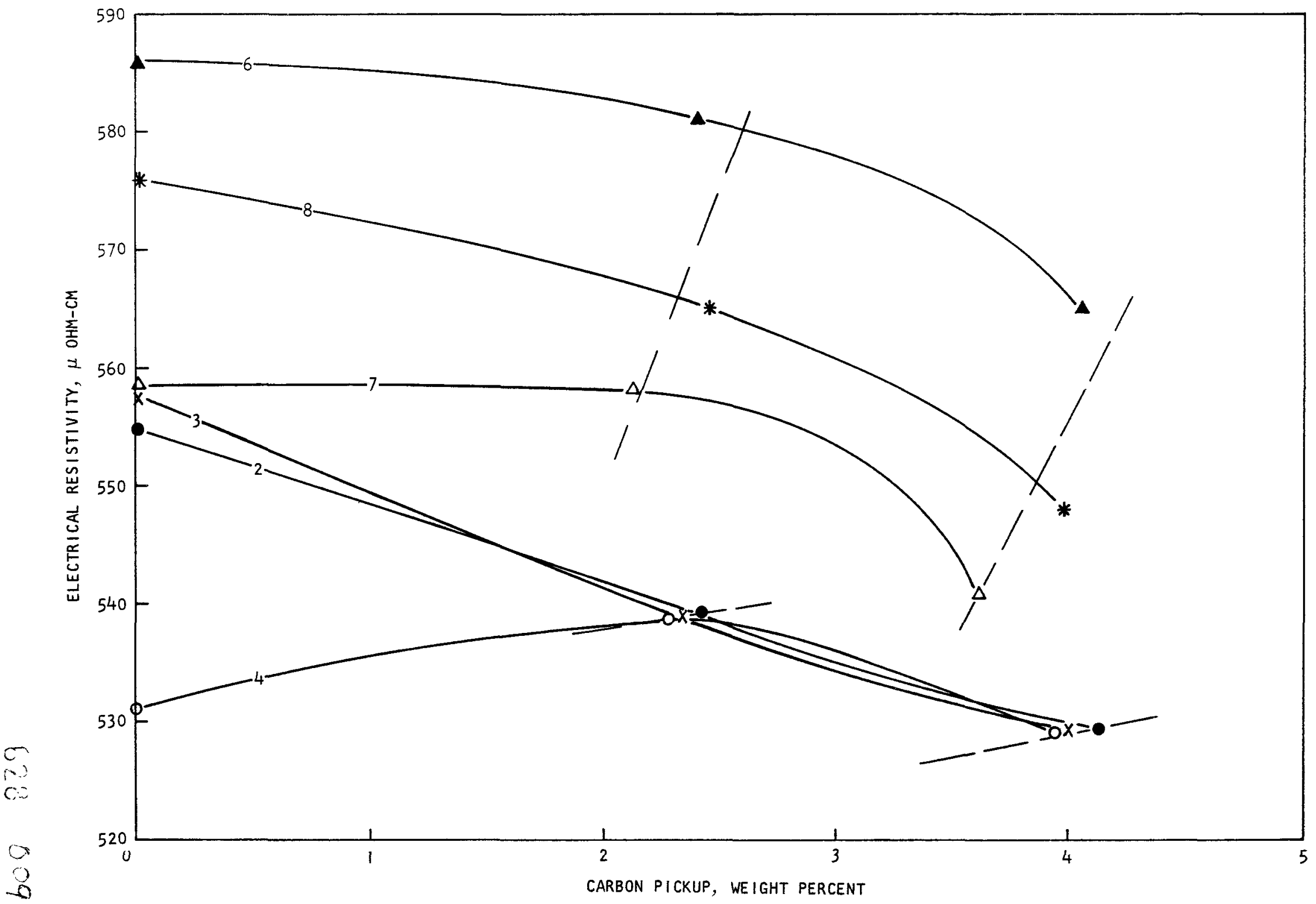

FIGURE 5 EFFECT OF CARBON PICKUP DURING IPIPREGNATION OF ELECTRICAL RESISTIVITY OF HIM-85 GRAPETIE 